\title{
Where have all the "lost" books gone?
}

\author{
By Edward V. Van Gemert
}

\section{Projecting overall rate of loss using a sample inventory}

n 1994-95 the University of WisconsinMadison conducted an inventory of its largest library. The goal of the inventory was to determine a baseline loss rate and to respond to concerns expressed by library users-especially members of faculty library committeesthat the loss of materials was inhibiting scholarly research. We sought to replace unsubstantiated perceptions with quantitative data to guide decisions about collection security.

The Madison campus is the largest in the University of Wisconsin system, home to 117 academic departments, 40,305 students, and 2,344 faculty. The General Library System (GLS) consists of Memorial Library (the central library for the humanities, social sciences, and area studies), College Library (the undergraduate library), Steenbock Library (the resource library for agricultural and life sciences), and a dozen branch or "member" libraries in a range of disciplines.

\section{The charge of the Lost Book Working Group}

The Lost Book Working Group was charged to report on the data currently available for lost and missing items across the General Library System; analyze both objective and subjective data to determine the extent of the problem; and recommend actions to the director to alleviate the current problems and keep our collections intact.

The membership of the Working Group included staff from central technical services, pub- lic services, collection development, and the member libraries.

\section{Member libraries}

Eleven member libraries responded to a request for data regarding the number of known lost monographs as of $1992-93$. Six were able to report figures:

$\begin{array}{lrl}\text { Art } & 2,154 \\ \text { Biology } & 935 \\ \text { Chemistry } & 82 \\ \text { Geology } & 200 \text { (approx.) } \\ \text { Physics } & 1,000 \text { (approx. since 1985) } \\ \text { Engineering } & 1,190 \text { (approx.) }\end{array}$

These figures reflect a narrow range of 0.5 percent to 0.58 percent of each library's monograph collection.

Three of these libraries do an inventory every two to three years; one does an annual inventory; one had an inventory in process; and one had done a partial inventory in 1991.

\section{Memorial Library's sample inventory}

Memorial Library is the largest library on the Madison campus with approximately $3.2 \mathrm{mil}-$ lion volumes in its collections. Since no inventory had been done of the Memorial Library stacks within the collective memory of present staff, the Lost Book Working Group decided to simulate an inventory, based on a sample of the stack monograph collection to establish baseline information on unlocated books.

A search of the literature did not uncover any models for conducting a sample inventory of a large academic research collection. Advice regarding the methodology and focus of a sample inventory was sought from professor 


\section{The second phase of searching by permanent staff located more than half of the volumes that student searchers could not find, suggesting a serious problem with inaccurate shelving.}

pert in searching the possible locations within the library. They took into account misshelving and searched the adjacent stack areas. They thoroughly understood oversized items which are shelved separately, and were knowledgeable about various reading room locations throughout the library.

In this phase, permanent staff found many of the books not located by student assistants. The original list of 2,142 missing titles was reduced to 973 . This represents 4.3 percent unaccounted for in the sample of 22,663 . We consider this to be our net figure for unlocated materials.

\section{Highest areas of unaccounted for titles}

A difference of means test was applied to the data to determine if certain areas had statistically significant higher rates of loss.

This analysis determined a rank order from high loss areas to low loss areas within the collection. A complete breakdown can be obtained from the author upon request.

As noted, the overall lost and or missing rate was 4.3 percent. The top four high loss areas were:

$\begin{array}{lll}\text { HD 1-4730 } & \begin{array}{c}\text { Economic History } \\ \text { and Conditions }\end{array} & 10.9 \% \\ \text { KF } & \text { Federal Law } & 10.3 \% \\ \text { PL 1-3316 } & \text { East Asian Languages } \\ & \text { \& Literature } & 9.8 \% \\ \text { L } & \text { Education } & 9.7 \%\end{array}$

These subjects experienced more than twice the average rate of loss.

Using the results from the one percent sample inventory; we projected the following figures for the LC collection as a whole:

- 97,300 items would not be on the shelf or otherwise accounted for;

- 4,200 items would be formally withdrawn from the collection based on shelflist information; and

- 800 items would be charged to lost on NOTIS.

\section{Titles misshelved}

As noted above, the second phase of searching by permanent staff located more than half of the volumes that student searchers 
could not find, suggesting a serious problem with inaccurate shelving. Therefore, Memorial Library's permanent staff shelvers were asked to report items found to be misshelved in the course of their regular work. These items were then checked against the circulation system to determine if search requests had been placed on these titles by patrons. In a two-month period, 1,225 items were reported as misshelved. This indicates that a large number of items are misshelved, and although not entirely relevant to the sample inventory, data were used by the Working Group to form a recommendation.

\section{Complete inventory of an LC subclass}

In response to concerns expressed by library users and librarians regarding unaccounted for titles in the Spanish literature portion of the PQ classification, a complete title-by-title inventory was unclertaken. The first phase studied 19thand 20th-century Mexican literature (PQ7297PQ7298.36).

This classification was recommended by faculty and selectors alike. There are 4,600 titles in this subclass. The findings are shown below:

$\begin{aligned} 169 & (3.7 \%) \text { charged out to patrons } \\ 3 & \text { Charged to lost } \\ 2 & \text { Charged to bindery and } \\ & \text { preservation collection } \\ 27 & \text { Withdrawn per the shelflist } \\ 159 & (3.4 \%) \text { not located }\end{aligned}$

The Lost Book Working Group concluded from this title-by-title inventory data that subclass PQ7297-PQ7298.36 was not, after all, a high loss area. In fact, it turned out to be lower than the average loss rate, contradicting user perceptions.

\section{Summary conclusions and recommendations to the director}

The Lost Book Working Group recommended that the following steps be taken:

1) Another sample inventory should be done to determine an annual loss rate.

2) Shelf reading should be done at least annually in the LC classes.

3) Special collection budget allocations should be made to selectors who can document losses in their subject areas.

4) An automated inventory process should be developed
5) The replacement fee for unreturned and lost materials should be increased.

6) Libraries should purchase up-to-date security detection systems.

\section{Conclusion}

The Memorial Library inventory demonstrated the feasibility of using a one percent sample to gather data on loss of materials.

The costs in student wages and permanent staff time proved to be affordable and reasonable. The 1994-95 sample inventory provides baseline data only. Since materials may have disappeared over a period of decades, we cannot calculate a current loss rate until we undertake further inventories, as planned for 1997 and periodically thereafter.

A one percent sample provides sufficient data for decision-making on a broad scale; it does not, of course, identify all missing items at the title level. Where there is reason to suspect systematic losses in a subject area, a full inventory can be conducted to identify titles for replacement.

Au. note: I'd like to thank the students and permanent staff of Memorial Library's User Services Department for their contribution to the completion of the inventory; members of the Lost Book Working Group; professor Jun Shao for his consultation on statistical methods and sampling; Gregg Gunderson for his consultation and data analysis; Susan Searing, the associate director for public services; David Henige, the African studies bibliographer; and Don Johnson, the editor for the General Library System, for their careful reading and editing of this article.

\section{Note}

1. "Missing" is a term used by circulation to indicate that an item cannot be located in the stacks. After searching, the item may or may not be located.

"Lost" is a term used when an item is searched for and not located after six months.

"Withdrawn" is a term to inclicate that the item has been declared lost. Circulation notifies central technical services to update the record for unavailability of the item. It may eventually be located or returned.

"Discarded" indicates that the library has intentionally removed the item from the collection. For example, the item is removed for preservation reasons. 